\title{
Evaluation of tumour necrosis factor-alpha and interleukin-1beta in an experimental pyelonephritis model induced with planktonic and biofilms cells of Pseudomonas aeruginosa
}

\author{
Rahul Mittal $\mathrm{PhD}^{1,2}$, Saroj Sharma MD FAMS ${ }^{2}$, Sanjay Chhibber $\mathrm{PhD}^{2}$, Kusum Harjai PhD ${ }^{2}$
}

\begin{abstract}
R Mittal, S Sharma, S Chhibber, K Harjai. Evaluation of tumour necrosis factor-alpha and interleukin-1beta in an experimental pyelonephritis model induced with planktonic and biofilms cells of Pseudomonas aeruginosa. Can J Infect Dis Med Microbiol 2009;20(3):e35-e42.

Urinary tract infections may induce severe inflammation, transient impairment in renal function and scar formation, ranging in severity from acute symptomatic pyelonephritis to chronic pyelonephritis, and have the potential to lead to renal failure and death. In the present study, the relationship between production of tumour necrosis factoralpha (TNF- $\alpha$ ), interleukin-1beta (IL-1 $\beta$ ), neutrophil recruitment, bacterial colonization and tissue damage was investigated using a mouse model of acute ascending pyelonephritis induced with planktonic and biofilm cells of Pseudomonas aeruginosa. Neutrophil influx correlated with rise in TNF- $\alpha$ and IL-1 $\beta$, indicating an association between these cytokines and neutrophil infiltration. However, biofilm cells of $P$ aeruginosa induced higher levels of TNF- $\alpha$ and IL-1 $\beta$ leading to higher neutrophil infiltration causing tissue damage, assessed in terms of malondialdehyde, lactate dehydrogenase and glutathione content, which may have contributed to bacterial persistence compared with their planktonic counterparts. The results of the present investigation suggest that exaggerated cytokine production during $P$ aeruginosa-induced pyelonephritis causes tissue damage operative through neutrophil recruitment leading to bacterial persistence in host tissues. The findings of the present study may be relevant for the better understanding of disease pathophysiology and for the future developments of preventive strategies against pyelonephritis based on antiinflammatory intervention.
\end{abstract}

Key Words: Biofilms; IL-1 $\beta$; Neutrophil recruitment; Pseudomonas aeruginosa; Pyelonephritis; TNF- $\alpha$

A cute pyelonephritis is one of the most common serious bacterial infections affecting humans throughout their lifespan. Without early diagnosis and rapid treatment, the progression of renal inflammation can result in renal scarring and permanent kidney damage. Postinfectious renal scarring is the most important complication after acute pyelonephritis, with an estimated incidence of $10 \%$ to $65 \%$ of cases (1). Renal scarring later in life may lead to the subsequent development of hypertension, proteinuria and even loss of renal function that is one of the major causes of end-stage renal disease in many countries $(2,3)$. The major hypothesis of the events leading to renal scarring or damage has been that bacterial products (eg, endotoxins such as lipopolysaccharides) stimulate the release
L'évaluation du facteur de nécrose tumorale alpha et de l'interleukine- 1 bêta dans un modèle expérimental de pyélonéphrite induit par des cellules planctoniques et de film biologique de Pseudomonas aeruginosa

Les infections urinaires peuvent induire une grave inflammation, une défaillance transitoire de la fonction rénale et la formation de cicatrices, dont la gravité varie d'une pyélonéphrite symptomatique aiguë à une pyélonéphrite chronique, et elles peuvent provoquer une insuffisance rénale et la mort. Dans la présente étude, on a étudié le lien entre la production du facteur de nécrose tumorale alpha (FNT- $\alpha$ ), l'interleukine-1 bêta (IL-1ß), le recrutement de neutrophiles, la colonisation bactérienne et les dommages tissulaires au moyen d'un modèle murin de pyélonéphrite ascendante aiguë induite par des cellules planctoniques et de film biologique de Pseudomonas aeruginosa. L'influx de neutrophiles était corrélé avec l'augmentation du FNT- $\alpha$ et de l'IL-1 $\beta$, indiquant une association entre ces cytokines et l'infiltration de neutrophiles. Cependant, les cellules de film biologique de $P$ aeruginosa induisaient des taux plus élevés de FNT- $\alpha$ et d'IL-1 $\beta$, entraînant une plus forte infiltration de neutrophiles responsables de dommages tissulaires évalués d'après leur contenu en malonaldéhyde, en lacticodéshydrogénase et en glutathione, qui peuvent avoir contribué à la persistance bactérienne par rapport à leurs homologues planctoniques. Selon les résultats de cette étude, une production exagérée de cytokine pendant une pyélonéphrite induite par le $P$ aeruginosa provoque des dommages tissulaires opérationnels par le recrutement de neutrophiles responsables d'une persistance bactérienne dans les tissus hôtes. Les observations tirées de la présente étude peuvent être utiles pour mieux comprendre la physiopathologie de la maladie et la future mise au point de stratégies préventives contre la pyélonéphrite, compte tenu de l'intervention anti-inflammatoire.

${ }^{1}$ Division of Infectious Diseases, Childrens Hospital Los Angeles, Los Angeles, California, USA; ${ }^{2}$ Department of Microbiology, Panjab University, Chandigarh, India

Correspondence: Dr Rahul Mittal, Division of Infectious Diseases, MS\#51, Childrens Hospital Los Angeles, 4650 Sunset Boulevard, Los Angeles,

California 90027, USA. Telephone 323-361-5809, e-mail ramittal@chla.usc.edu and mittal05@gmail.com 
tendency to form biofilms on the surface of urinary catheters leading to recurrent and chronic infections that result in significant morbidity and mortality (12-17). Biofilm bacteria form structured communities of cells embedded in an extracellular polymeric matrix (18-21). Biofilms are resistant to antimicrobial agents as well as to host defense mechanisms, leading to difficulty in eradication (22-28). Biofilms also provide an ideal niche for the exchange of extrachromosomal DNA responsible for antibiotic resistance, virulence factors and environmental survival capabilities at accelerated rates, making it a perfect milieu for the emergence of drug-resistant pathogens (29-31).

Uropathogenic microorganisms cause disease by cytotoxic activities and also by activating a local and systemic inflammatory response. The course and severity of the disease are determined by the efficiency of the local or systemic immunological and nonimmunological defense mechanism of the host. A wide variety of cells including lymphocytes, endothelial cells and urinary tract as well as renal epithelial cells produce cytokines in response to Gram-negative bacteria or their products (32). Cytokines are small proteins important for the orchestration of the inflammatory process. The most potent proinflammatory cytokines are tumour necrosis factor-alpha (TNF- $\alpha$ ) and interleukin-1beta (IL-1 $\beta$ ), which are produced in response to bacterial pathogens and constitute important inflammatory cytokines in various infections such as septicemia, meningitis and pyelonephritis in children (33-36). TNF- $\alpha$, a proinflammatory cytokine, has been reported to play an important role in UTIs. Increased levels of this cytokine and its receptors have been observed in urine and serum samples of patients having acute pyelonephritis (37). TNF- $\alpha$ also stimulates production of other proinflammatory cytokines such as IL-1 $\beta$. IL- $1 \beta$ was originally described as a fever-producing endogenous pyrogen that appears early during the inflammatory processes, and is responsible for acute-phase reactions including fever production, increased secretion of acute-phase reactants such as C-reactive protein and peripheral neutrophilia (38). Higher levels of this cytokine have been observed in bronchoalveolar lavage fluid of cystic fibrosis patients compared with healthy controls $(39,40)$, indicating importance of IL-1 in the infectious process. Thus, TNF- $\alpha$ and IL- $1 \beta$ are potent multifunctional cytokines that play a central role in inflammation and immunity. No reports are available in literature regarding production of TNF- $\alpha$ as well as IL-1 $\beta$ and their role in acute pyelonephritis caused by $P$ aeruginosa. Because $P$ aeruginosa is the third most common pathogen, accounting for $40 \%$ of cases of catheter-associated UTIs (41), and possesses a wide arsenal of virulence factors capable of stimulating epithelial cells to secrete cytokines $(42,43,9)$, there is a need to understand the precise contribution of cytokines in the disease process caused by this pathogen. In the present investigation, urine and renal cytokine response to bacterial infection and their role in acute pyelonephritis was studied following induction of acute pyelonephritis in mice with planktonic and biofilms cells of $P$ aeruginosa. TNF- $\alpha$ and IL- $1 \beta$ were chosen for investigation in this study over other urinary markers because these cytokines appear early in the immune response cascade and may play a pivotal role in deciding the ultimate outcome of an infection. In addition, the assessment of these cytokines is clinically feasible in urine and potentially useful in acute pyelonephritis due to their role in systemic inflammation.

\section{METHODS}

\section{Organisms}

A urinary isolate of P aeruginosa, PA5, employed in earlier studies (44-46), isolated from a hospitalized patient having complicated UTI and serotyped as $\mathrm{O} 11$ by the Laboratory of HealthCare Associated Infection, London was used. This strain produced most of the recognized virulence factors such as alginate, exotoxin $\mathrm{A}$, exoenzyme $\mathrm{S}$, phopholipase $\mathrm{C}$, protease, elastase, pyochelin, pyoverdin and hemolysin. In addition, a standard strain of $P$ aeruginosa, $\mathrm{PAO}$, producing most of the above-mentioned virulence factors, was obtained from Dr Barbara H Iglewski, University of Rochester, Rochester, New York. Both strains were grown overnight in nutrient broth at $37^{\circ} \mathrm{C}$ and harvested by centrifugation. Cells were washed three times with phosphate-buffer saline (PBS), resuspended to a concentration of $1 \times 10^{8}$ organisms per $\mathrm{mL}$ in PBS (confirmed by viable cell counting) and were used as planktonic cells for induction of infection in mice.

\section{Generation of biofilm cells}

The method of Ladd et al (47) as standardized in our laboratory by Mittal et al (44) was followed for generation of biofilms. Both PA5 and PAO strains of $P$ aeruginosa were used to generate biofilm cells. Foley catheters (Bardia, Bard Urology, United Kingdom) were cut into $1.0 \mathrm{~cm}$ pieces, inoculated with $100 \mu \mathrm{L}$ of overnight grown culture and incubated at $37^{\circ} \mathrm{C}$. Every $24 \mathrm{~h}$ the catheter pieces were removed from each flask, rinsed three times with PBS and transferred to the new flask containing fresh medium until day 4 . On day 4 , the catheter pieces were rinsed three times with PBS to remove adherent bacteria and sliced longitudinally into equal halves. Cells were removed from the surface of catheter pieces by scraping the inner surface with a sterile scalpel blade. The dispersed sample was then centrifuged, and the biofilm cells were suspended in $1 \mathrm{~mL}$ PBS. Bacterial concentration was confirmed by absorbance at $600 \mathrm{~nm}$ and viable counts.

\section{Induction of ascending pyelonephritis}

For induction of ascending pyelonephritis, female LACA strain mice, six to eight weeks of age, weighing $25 \pm 5 \mathrm{~g}$, obtained from Central Animal House, Panjab University, Chandigarh, India, were used. Animals were kept in clean polypropylene cages under pathogen-free conditions and given food and water ad libitum. The animals' bladders were pressed to evacuate urine before instillation. Urine was checked for preinfection bacteriuria by culturing on selective media. A soft intramedic polyethylene catheter, nonradiopaque (outer diameter $0.61 \mathrm{~mm}$, Clay Adams, USA) was inserted into the bladder through the urethral meatus, and $0.05 \mathrm{~mL}$ of inoculum containing $10^{8}$ colony forming units/mL (confirmed by absorbance at $600 \mathrm{~nm}$ and viable counts) was slowly injected into the bladder to avoid leakage $(44,45,48,49)$. The catheter was kept in place for $10 \mathrm{~min}$ after completion of instillation and then it was withdrawn carefully. In the control group, mice were injected intraurethrally with $0.05 \mathrm{~mL}$ of pyrogen-free saline through the catheter. No obstruction or further manipulation of the urinary tract was performed. Eight mice were used for each strain and for each time interval separately for planktonic and biofilm cell forms. All animal experiments were carried out in two groups in triplicate. The study protocol was approved by the institutional ethical committee for animal experimentation. 


\section{Bacteriological examination}

Animals were sacrificed at one, three, five and seven days postinfection. Renal tissue was removed aseptically and sliced into two equal halves. One half was used for bacteriological examination and the other half was used for histopathology. One-half of the renal tissue was then weighed and homogenized in $1 \mathrm{~mL}$ of sterile PBS. This homogenized tissue was plated on cetrimide agar plates. Quantitative bacterial counts per gram of the renal tissue were calculated (44).

\section{Histopathological examination}

The other one-half of the renal tissue was fixed in 10\% buffered formal saline and was dehydrated in ethanol gradient of $30 \%$ to $100 \%$. Tissues were then embedded in wax, sectioned and stained with hemotoxylin and eosin (50). The medulla, cortex, calyx and subcalyx of each kidney were evaluated on a semiquantitative scale of 0 to 4 . These individual scores were then added to obtain an overall severity score, which ranged from 0 to 16. The histopathological examination was performed by a pathologist experienced in urinary tract pathology.

\section{Cytokine response}

TNF- $\alpha$ and IL-1 $\beta$ in urine as well as in renal tissue was quantitated by using an ELISA kit (R\&D Systems, USA). Urine samples were centrifuged and the supernatant was stored at $-70^{\circ} \mathrm{C}$ for chemokine analysis. Renal tissue was removed, immediately snap frozen and stored at $-70^{\circ} \mathrm{C}$. Tissues were homogenized in $3 \mathrm{~mL}$ of lysis buffer containing $0.5 \%$ Triton $\mathrm{X}-100,150 \mathrm{mM} \mathrm{NaCl}, 15 \mathrm{mM}$ Tris, $1 \mathrm{mM} \mathrm{CaCl}_{2}$ and $1 \mathrm{mM}$ $\mathrm{MgCl}_{2}, \mathrm{pH} 7.4$, using a tissue homogenizer. Homogenates were incubated on ice for $30 \mathrm{~min}$, then centrifuged at $1500 \times \mathrm{g}$ for $10 \mathrm{~min}$; supernatants were collected and passed through a $0.45 \mu \mathrm{m}$ filter and used for ELISA. ELISA was carried out according to the manufacturer's instructions.

\section{Assessment of neutrophil response}

The number of neutrophils migrating across the mucosa into the urine was quantitated in uncentrifuged urine using a hemocytometer chamber (44). Tissue neutrophils were quantitated using a myeloperoxidase (MPO) assay (40). Renal tissue was homogenized in $2 \mathrm{ml}$ of $50 \mathrm{mM}$ potassium phosphate, $\mathrm{pH} 6.0$ with $5 \%$ hexadecyltrimethylammonium bromide and $5 \mathrm{mM}$ EDTA. Homogenates were sonicated and centrifuged. Supernatants were mixed at the ratio of 1:15 with assay buffer and read at $490 \mathrm{~nm}$. MPO units were calculated as the change in absorbance over time.

Determination of lactate dehydrogenase (LDH), malondialdehyde (MDA) and glutathione (GSH): LDH levels were determined using QuantiChrom LDH kit (BioAssay systems, USA). MDA levels were determined following method of Wills (51). Briefly, tissue supernatant was added to equal amount of Tris $\mathrm{HCl}(0.1 \mathrm{M}, \mathrm{pH} 7.4)$ and incubated at $37^{\circ} \mathrm{C}$ for $2 \mathrm{~h}$. After incubation, trichloroacetic acid was added and centrifuged at $700 \times g$ for $10 \mathrm{~min}$. Supernatant was mixed with equal volume of thiobarbituric acid $(0.67 \% \mathrm{w} / \mathrm{v})$ and kept in boiling water bath for $10 \mathrm{~min}$. After cooling, volume was made to $3 \mathrm{~mL}$ with double distilled water and absorbance was taken at $532 \mathrm{~nm}$. Amount of MDA formed was expressed in $\mathrm{nmol} / \mathrm{mg}$ protein using an extinction coefficient of $1.56 \times 10^{5} \mathrm{M}^{-1} \mathrm{~cm}^{-1}$. GSH content was determined following method of Tugtepe et al (52). Briefly, after centrifugation at $2000 \times \mathrm{g}$ for $10 \mathrm{~min}$,
$0.5 \mathrm{~mL}$ of supernatant was added to $2 \mathrm{~mL}$ of $0.3 \mathrm{~mol} / \mathrm{L}$ $\mathrm{Na}_{2} \mathrm{HPO}_{4} \cdot 2 \mathrm{H}_{2} \mathrm{O}$ solution. A $0.2 \mathrm{~mL}$ solution of dithiobisnitrobenzoate $(0.4 \mathrm{mg} / \mathrm{mL} 1 \%$ sodium citrate) was added and the absorbance at $412 \mathrm{~nm}$ was measured immediately after mixing. GSH levels were calculated using an extinction coefficient of $1.36 \times 10^{5} \mathrm{M}^{-1} \mathrm{~cm}^{-1}$. Results were expressed in $\mathrm{nmol} / \mathrm{mg}$ protein.

\section{Statistical analysis}

For statistical analysis of data, ANOVA, Fischer test and Student's $t$ test was applied, and $\mathrm{P}$ values were calculated. $\mathrm{P}<0.05$ was considered statistically significant.

\section{RESULTS}

In the present study, production of TNF- $\alpha$ and IL- $1 \beta$ was studied following intravesical instillation of planktonic and biofilms cells of $P$ aeruginosa. TNF- $\alpha$ and IL-1 $\beta$ was detectable at postinfection day 1 in urine and renal tissue and peaked at postinfection day 3 in planktonic cell-infected mice and postinfection day 5 in biofilm cell-instilled mice. TNF- $\alpha$ and IL-1 $\beta$ levels were significantly higher in mice infected with biofilm cells compared with planktonic cell-instilled mice $(\mathrm{P}<0.001)$ (Figure 1).

The virulence potential of planktonic and biofilm cells of $P$ aeruginosa was studied in vivo in a mouse model of ascending pyelonephritis. At different stages/course of infection, the presence of organisms in urine and renal tissue was checked. Peak renal bacterial counts were observed on postinfection day 3 in mice infected with planktonic cells and on postinfection day 5 in biofilm cell-instilled mice. Peak urine counts were observed on postinfection day 3 in case of both planktonic and biofilm cell-instilled mice. However, bacterial counts were significantly higher in mice infected with biofilm cells of $P$ aeruginosa compared with mice infected with planktonic cells at all time intervals $(\mathrm{P}<0.001)$. This trend was observed with both strains of $P$ aeruginosa (Figure 2 ).

Neutrophil recruitment into renal tissue was quantitated by MPO assay. An influx of neutrophils started at postinfection day 1 , reached a peak by postinfection day 3 in planktonic cellinstilled mice and on postinfection day 5 in biofilm cellinstilled mice, showing a decrease thereafter on postinfection day 7 (Figure 3). In urine, peak neutrophil infiltration was observed on postinfection day 3 in both planktonic and biofilm cell-infected mice (Figure 3). Neutrophil recruitment was significantly higher in biofilm cell-infected mice compared with planktonic cell-instilled mice $(\mathrm{P}<0.001)$.

Tissue damage in experimental animals following infection with planktonic and biofilm cells of $P$ aeruginosa was assessed in terms of increase in LDH and MDA levels. With increase in postinfection time period from postinfection day 1 to 7 , there was a gradual increase in $\mathrm{LDH}$ and MDA production in urine and renal tissue as well as a decrease in renal GSH content indicating tissue damage and oxidative stress (Figure 4). MDA and LDH levels were significantly higher whereas GSH content was lower in mice infected with biofilm cells compared with those infected with planktonic cells of $P$ aeruginosa $(P<0.001)$. This was observed in both strains of $P$ aeruginosa.

Histopathological evaluation of renal tissue of mice infected with biofilm cells of $P$ aeruginosa revealed severe inflammation along with shedding of cells and vascular permeability compared to control uninfected mice (Figures 5A and 5B). On 

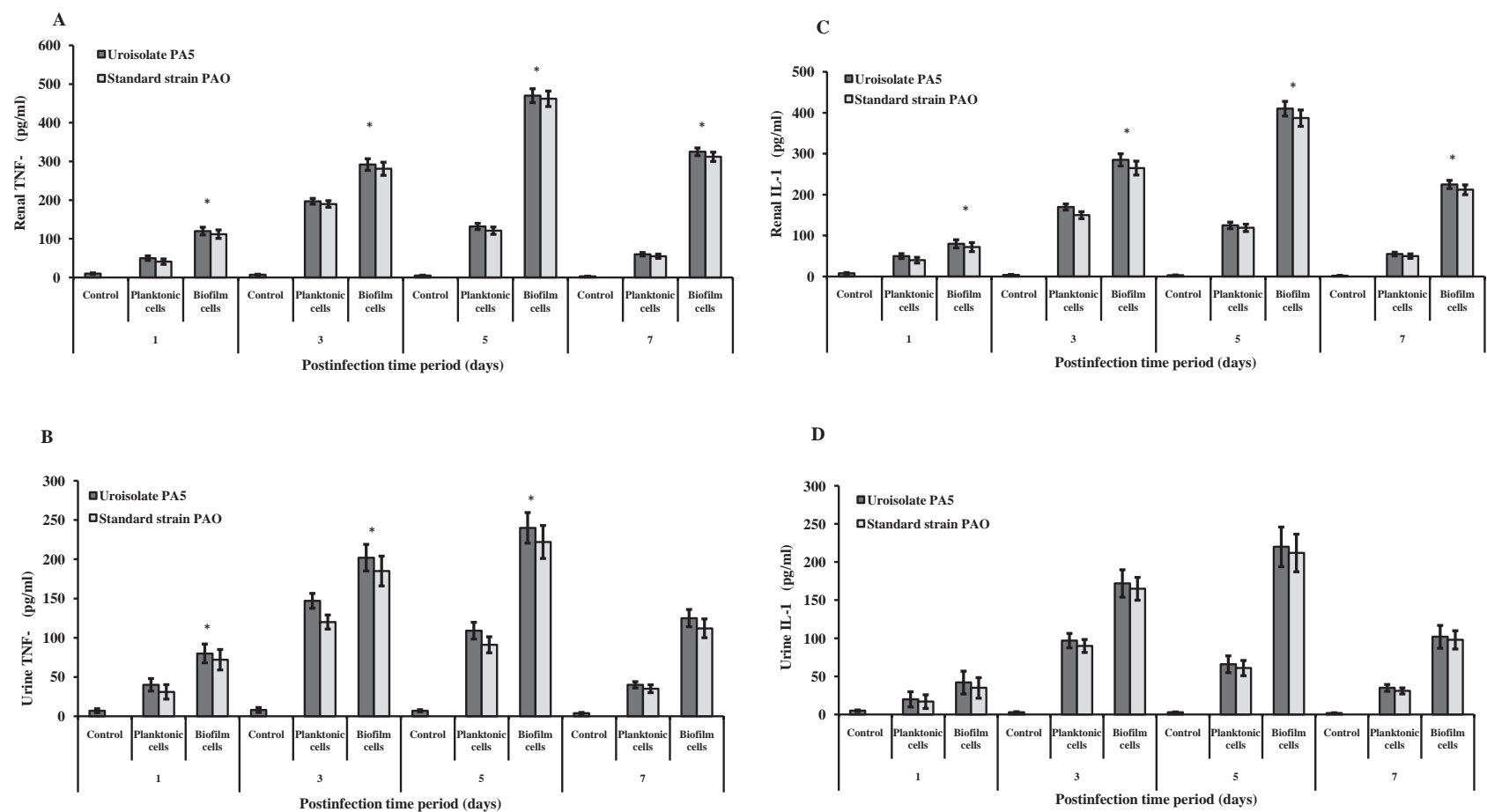

Figure 1) Cytokine production in mice infected with uroisolate (PA5) and standard strain (PAO) of Pseudomonas aeruginosa. Saline-treated mice served as control. Tumour necrosis factor-alpha (TNF- $\alpha)$ and interleukin-1beta (IL-1ß) levels were estimated in renal tissue (A and $\mathrm{C})$ and urine ( $\mathrm{B}$ and $\mathbf{D})$ of control mice or mice infected with planktonic and biofilm cells of $\mathrm{P}$ aeruginosa using ELISA. The data represent mean $\pm S D$ values and are representative of three independent measurements carried out in triplicate. $* P<0.001$ planktonic versus biofilm cells
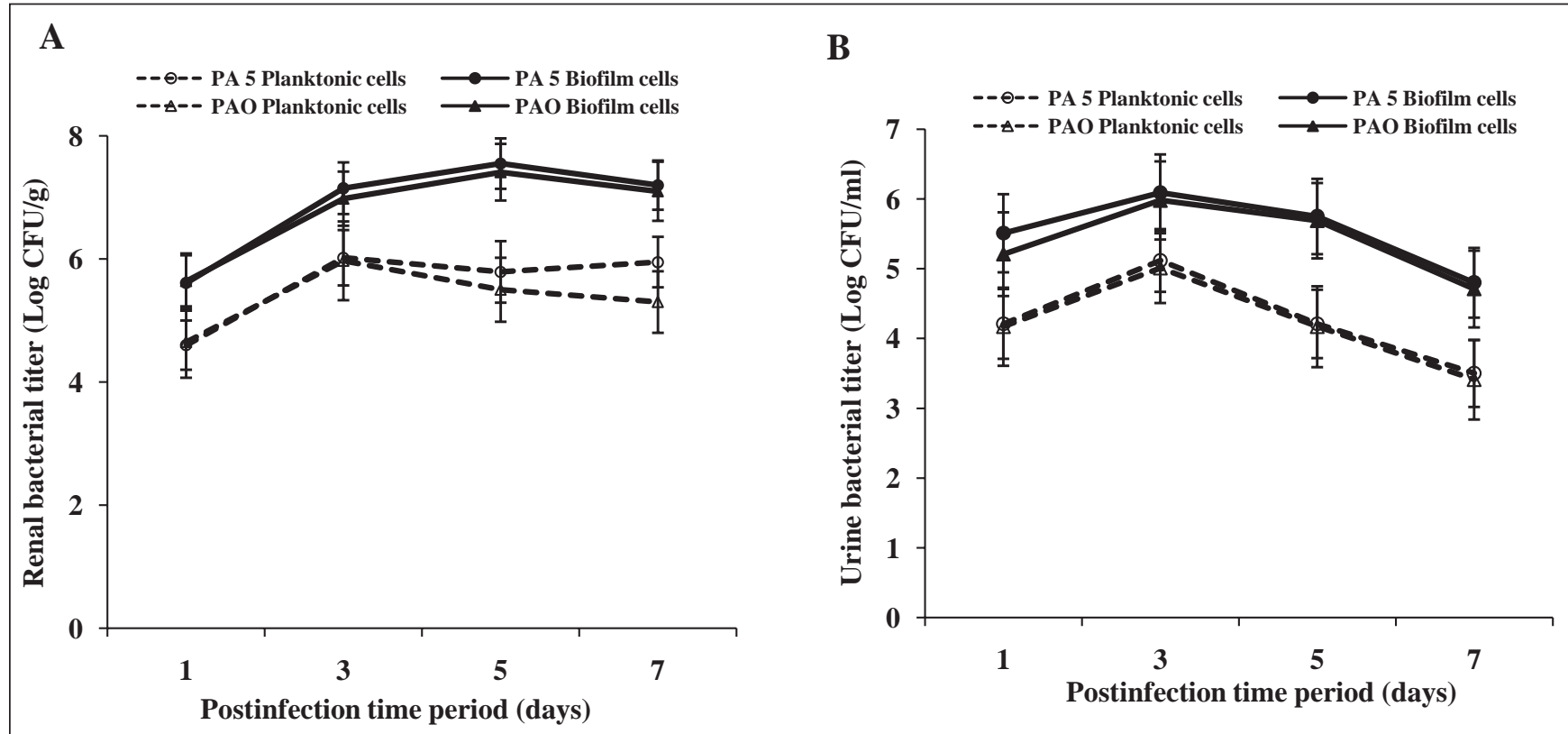

Figure 2) Bacterial titre in renal tissue (A) and urine (B) of mice following intravesical instillation with planktonic and biofilm cells of uroisolate (PA5) and standard strain (PAO) of Pseudomonas aeruginosa. The bacterial load was significantly higher in biofilm cell-instilled mice than planktonic cell-instilled mice. The data represent mean \pm SD values and are representative of two independent experiments carried out in triplicate. $P<0.001$ planktonic versus biofilm cells

the other hand, moderate inflammation was observed in renal tissue of planktonic cell-instilled mice (Figure 5C). Neutrophil infiltration was more in the renal pelvis, which extended into the medulla and cortex. Polymorphonuclear neutrophils (PMNs) were seen disseminated throughout the renal tissues in clusters in biofilm cell-instilled mice. Renal severity scores ranged from +3 to +8 in 


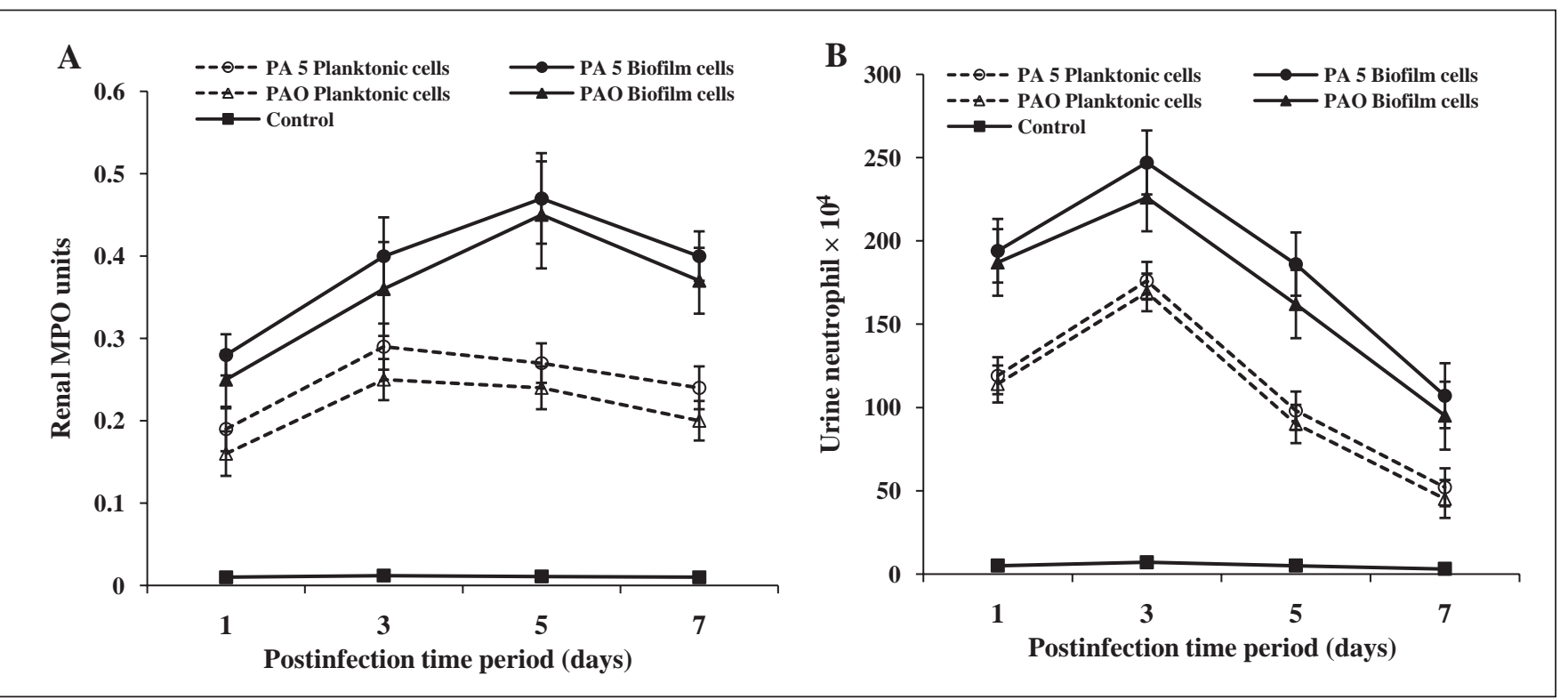

Figure 3) Neutrophil recruitment in mice following infection with uroisolate (PA5) and standard strain (PAO) of Pseudomonas aeruginosa. Myeloperoxidase (MPO) activity in renal tissue (A) and neutrophil number in urine (B) of mice infected with planktonic and biofilm cells of $\mathrm{P}$ aeruginosa was assessed as described in the Methods section. The data represent mean \pm SD values and are representative of five independent measurements carried out in triplicate. $P<0.001$ planktonic versus biofilm cells

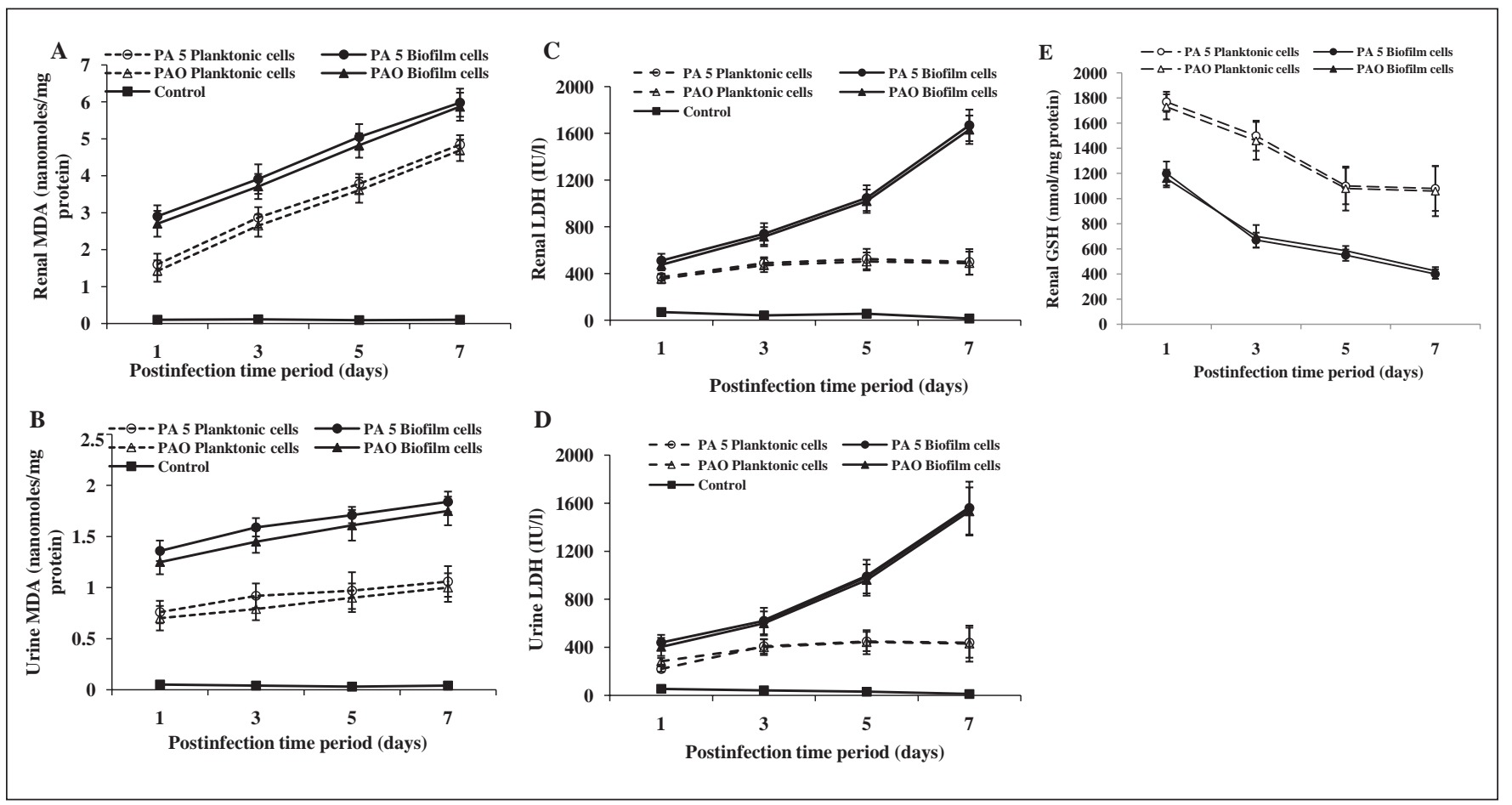

Figure 4) Tissue damage markers in renal tissue and urine of mice infected with uroisolate (PA5) and standard strain (PAO) of Pseudomonas aeruginosa. Renal tissues and urine of mice infected with planktonic and biofilm cells of $\mathrm{P}$ aeruginosa were analyzed for malondialdehyde (MDA) (A and B), lactate dehydrogenase (LDH) (C and D) and glutathione (GSH) (E) as described in materials and methods. The data represent mean \pm SD values and are representative of four independent measurements carried out in triplicate. P<0.001 planktonic versus biofilm cells

case of biofilm cells whereas it varied from +2 to +5 in case of planktonic cells (Table 1).

\section{DISCUSSION}

UTIs activate both mucosal and systemic inflammatory responses (53). Local response includes the influx of granulocytes,macrophages and monocytes as well as the production of different cytokines (54). The frequency of cytokine release as well as the amount and type of cytokines secreted from epithelial cells after bacterial attachment may determine the extent and severity of infectious process (32). Chemotactic cytokines such as TNF- $\alpha$ and IL-1 $\beta$ play a key role in 

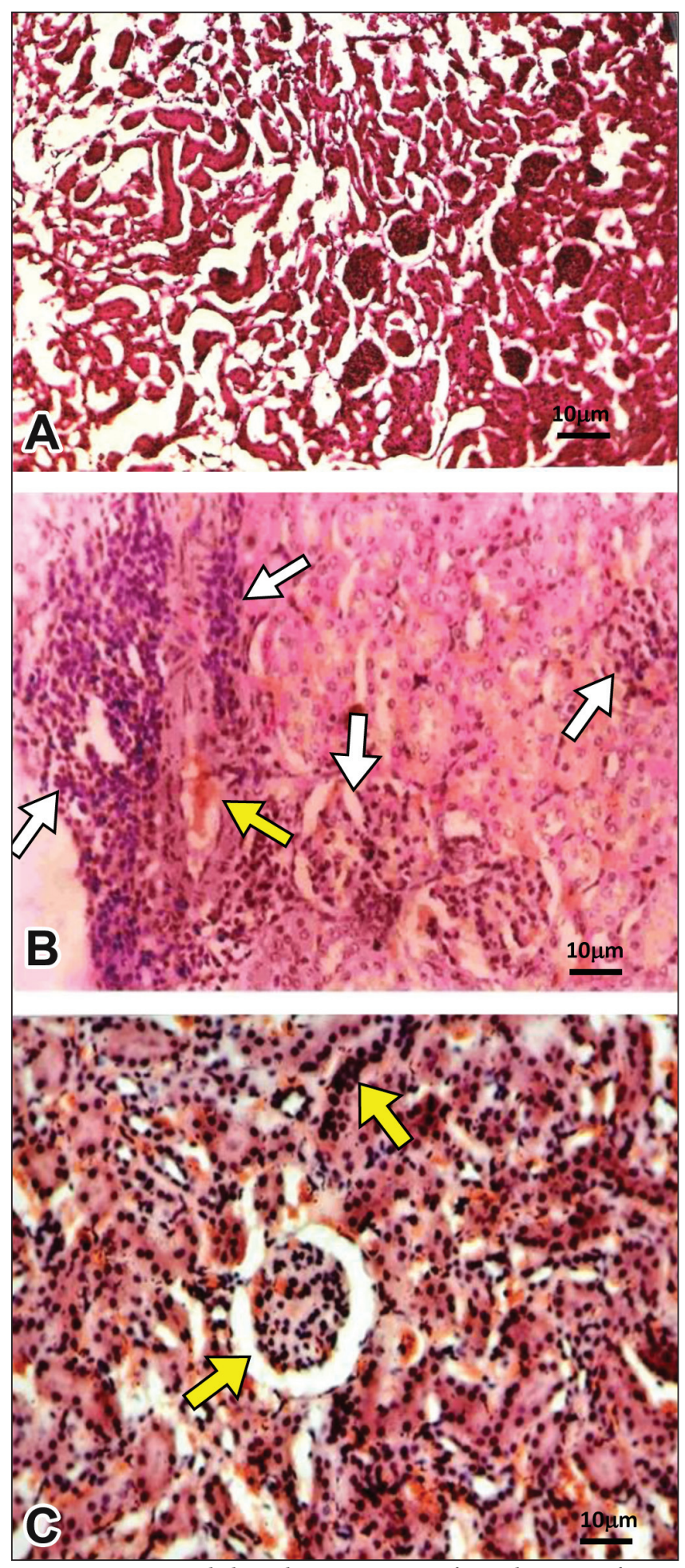

Figure 5) Histopathological examination of renal tissue of mice infected with Pseudomonas aeruginosa. A Renal tissue of salineinstilled mice (controls). B Severe inflammation (white arrows) along with vascular permeability (yellow arrow) was observable in renal tissue of mice following infection with biofilm cells of $P$ aeruginosa. On the other hand, moderate inflammation (yellow arrows) was seen in renal tissue of mice infected with planktonic cells of $\mathrm{P}$ aeruginosa $(\mathrm{C})$

transuroepithelial migration of polymorphonuclear cells induced by bacteria $(38,53)$. In the present report, we have investigated the production of TNF- $\alpha$ and IL-1 $\beta$ in a murine
TABLE 1

Renal severity scores in pyelonephritic mice

\begin{tabular}{|c|c|c|c|c|c|c|c|c|}
\hline & \multicolumn{8}{|c|}{ Severity scores } \\
\hline & \multicolumn{2}{|c|}{ Day 1} & \multicolumn{2}{|c|}{ Day 3} & \multicolumn{2}{|c|}{ Day 5} & \multicolumn{2}{|c|}{ Day 7} \\
\hline & PA5 & PAO & PA5 & PAO & PA5 & PAO & PA5 & PAO \\
\hline $\begin{array}{l}\text { Planktonic } \\
\text { cells }\end{array}$ & $2 \pm 0.19$ & $2 \pm 0.16$ & $3 \pm 0.22$ & $3 \pm 0.25$ & $4 \pm 0.27$ & $4 \pm 0.24$ & $5 \pm 0.34$ & $4 \pm 0.32$ \\
\hline $\begin{array}{l}\text { *Biofilm } \\
\text { cells }\end{array}$ & $5 \pm 0.29$ & $3 \pm 0.21$ & $6 \pm 0.34$ & $5 \pm 0.30$ & $7 \pm 0.38$ & $5 \pm 0.28$ & $8 \pm 0.41$ & $7 \pm 0.35$ \\
\hline
\end{tabular}

model of unobstructed, ascending pyelonephritis that closely mimicks human clinical situations, induced with planktonic and biofilm cells of $P$ aeruginosa. Peak production of TNF- $\alpha$ and IL-1 $\beta$ as well as bacterial counts in urine and renal tissue was observed on postinfection day 3 in mice infected with planktonic cells and on postinfection day 5 in biofilm cellinstilled experimental animals. In addition, neutrophil influx correlated with the rise in TNF- $\alpha$ and IL-1 $\beta$ at different time intervals tested, which indicates an association between these cytokines and recruitment of PMNs. However, biofilm cells of $P$ aeruginosa produced higher levels of these cytokines compared with their planktonic counterparts. In this context, Tugtepe et al (52) also observed higher levels of TNF- $\alpha$ in the serum of pyelonephritic rats following infection with Escherichia coli compared with uninfected control mice, as observed in the present study. Kinetics of IL-1 production was studied by Rudner et al (55) in $P$ aeruginosa-induced corneal infection. These workers observed peak expression of IL-1 between the first and third day, which returned to baseline preinfection levels on postinfection day 7. It was suggested that prolonged elevation of IL-1 expression contributed to corneal destruction through continued influx of neutrophils in response to increased production of macrophage inflammatory protein-2, whereas timely downregulation of IL-1 helped in bacterial clearance. It is also well known that IL-1 $\beta$ induces chemokines and may be involved in the scarring process partly by inducing transforming growth factor-beta and matrix metalloproteinases. It thus appears that timely dowregulation of TNF- $\alpha$ and IL-1 $\beta$ may help in the bacterial clearance but require delicate balance between protective and destructive responses operative through these cytokines.

Acute pyelonephritis is accompanied with inflammatory responses leading to PMN recruitment at the site of infection (52). Neutrophils, which leave the bloodstream, migrate to the tissue, crossing the epithelial barrier and finally reaching into the lumen. In this context, therefore, study of presence of neutrophils in the urine and renal tissue carries importance. MPO assay as well as histopathology revealed neutrophil recruitment in renal tissue of mice following infection with $P$ aeruginosa. However, concomitant with the increased infiltration of neutrophils, biofilm cells of $P$ aeruginosa were still demonstrable in high numbers in urine and renal tissue of mice compared with planktonic cells, indicating that biofilm cells are resistant to neutrophil-mediated killing. In this regard, Jensen et al (56) and Takeoka et al (57) observed a lesser degree of oxidative burst activity of PMNs following stimulation by biofilm cells compared with stimulation caused by planktonic cells. Walker et al (58) showed that components 
from neutrophils could serve as a biological matrix to facilitate $P$ aeruginosa biofilm formation. These authors reported that human neutrophils could serve to enhance the initial development of $P$ aeruginosa biofilms.

Available experimental data from the literature confirm that products of lipid-peroxidation act as markers for determining the extent of tissue damage. To measure this, researchers have quantitated $\mathrm{LDH}$ and MDA levels for estimating the intensity of lipid peroxidation in tissues because it offers speed, reliability and sensitivity (52). In addition, pyelonephritis has been reported to be accompanied with oxidative stress leading to depletion in renal GSH. GSH is the major antioxidant produced by the cell, protecting it from free radicals. It plays a crucial role in maintaining a normal balance between oxidation and anti-oxidation. GSH deficiency contributes to oxidative stress and therefore appears to play a key role in the pathology of many diseases. In the present study, biofilm cells of $P$ aeruginosa produced higher levels of MDA and $\mathrm{LDH}$ while renal GSH content was depleted indicating oxidative stress and tissue damage, which may be attributed to higher neutrophil influx due to increased TNF- $\alpha$ as well as IL-1 $\beta$ production. Pavlova et al (59) also reported that total antioxidant activity is diminished to a great extent due to antioxidant exhaustion and inhibition in pyelonephritis. In accordance with the present

\section{REFERENCES}

1. Rushton HG. Urinary tract infections in children: Epidemiology, evaluation, and management. Pediatr Clin North Am 1997;44:1133-69.

2. Jakobsson B, Berg U, Svensson L. Renal scarring after acute pyelonephritis. Arch Dis Child 1994;70:111-5.

3. Ott U, Busch M, Steiner T, et al. Renal failure, sepsis, and bilateral kidney tumors. Xanthogranulomatous pyelonephritis. Kidney Int 2008;73:787-8.

4. Zasloff M. Antimicrobial peptides, innate immunity, and the normally sterile urinary tract. J Am Soc Nephrol 2007;18:2810-6.

5. Bodey GP, Bolivar R, Fainstein V, Jadeja L. Infections caused by Pseudomonas aeruginosa. Rev Infect Dis 1983;5:279-313.

6. Lyczak JB, Cannon C, Pier GB. Establishment of Pseudomonas aeruginosa infection: Lessons from a versatile opportunist. Microb Infect 2000;2:1051-60.

7. Gómez MI, Prince A. Opportunistic infections in lung disease: Pseudomonas infections in cystic fibrosis. Curr Opin Pharmacol 2007;7:244-51.

8. Engel J, Balachandran P. Role of Pseudomonas aeruginosa type III effectors in disease. Curr Opin Microbiol 2009;12:61-6.

9. Girard G, Bloemberg GV. Central role of quorum sensing in regulating the production of pathogenicity factors in Pseudomonas aeruginosa. Future Microbiol 2008;3:97-106.

10. Sadikot RT, Blackwell TS, Christman JW, Prince AS. Pathogenhost interactions in Pseudomonas aeruginosa pneumonia. Am J Respir Crit Care Med 2005;171:1209-23.

11. Mittal R, Khandwaha RK, Gupta V, Mittal PK, Harjai K. Phenotypic characters of urinary isolates of Pseudomonas aeruginosa $\&$ their association with mouse renal colonization. Indian J Med Res 2006;123:67-72.

12. Driscoll JA, Brody SL, Kollef MH. The epidemiology, pathogenesis and treatment of Pseudomonas aeruginosa infections. Drugs 2007;67:351-8

13. Macleod SM, Stickler DJ. Species interactions in mixed-community crystalline biofilms on urinary catheters. J Med Microbiol 2007;56:1549-57.

14. Stickler DJ. Susceptibility of antibiotic-resistant Gram-negative bacteria to biocides: A perspective from the study of catheter biofilms. J Appl Microbiol. 2002;92(Suppl):163S-70S.

15. Hoiby N, Krogh Johansen H, Moser C, Song Z, Ciofu O, Kharazmi A. Pseudomonas aeruginosa and the in vitro and in vivo biofilm mode of growth. Microbes Infect 2001;3:23-35. findings, it was previously shown that depletion of PMNs in rats reduces the renal destruction in exudative E coli pyelonephritis and protects from chronic parenchymal destruction and scarring (60). Moreover, it was demonstrated that permanent tissue damage, which occurs during acute pyelonephritis, could be prevented through the inhibition of MPO system (61).

\section{CONCLUSIONS}

The results of the current study suggest that TNF- $\alpha$ and IL-1 $\beta$ production may have the potential to influence the establishment of UTI. The findings of this investigation can be gainfully employed for future studies where profile of TNF- $\alpha$ and IL- $1 \beta$ induced by different uropathogens may be studied critically following infection. A better knowledge of chemokine action and regulation during pyelonephritis may therefore help to explore new therapeutic strategies in the future with far reaching consequences.

ACKNOWLEDGEMENTS: We are thankful to Judith Glover, Laboratory of HealthCare Associated Infection, London, for serotyping of Pseudomonas aeruginosa. We are also grateful to Dr Barbara H Iglewski for providing us with a standard strain of $P$ aeruginosa. This work was supported by a grant from Indian Council of Medical Research, New Delhi, India.

16. Costerton JW, Lewandowski Z, Caldwell DE, Korber DR, LappinScott HM. Microbial biofilms. Annu Rev Microbiol 1995;49:711-45.

17. Hall-Stoodley L, Stoodley P. Evolving concepts in biofilm infections. Cell Microbiol 2009;11:1034-43.

18. Ma L, Conover M, Lu H, Parsek MR, Bayles K, Wozniak DJ. Assembly and development of the Pseudomonas aeruginosa biofilm matrix. PLoS Pathog 2009;5:e1000354.

19. Costerton JW, Lewandowski Z, DeBeer D, Caldwell D, Korber D, James G. Biofilms, the customized microniche. J Bacteriol 1994;176:2137-42.

20. Donlan RM. Biofilms: Microbial life on surfaces. Emerg Infect Dis 2002;8:881-90.

21. Mah TF, O'Toole GA. Mechanisms of biofilm resistance to antimicrobial agents. Trends Microbiol 2001;9:34-9.

22. Hall-Stoodley L, Stoodley P. Biofilm formation and dispersal and the transmission of human pathogens. Trends Microbiol 2005;13:7-10.

23. Parsek MR, Tolker-Nielsen T. Pattern formation in Pseudomonas aeruginosa biofilms. Curr Opin Microbiol 2008;11:560-6.

24. Costerton JW, Stewart PS, Greenberg EP. Bacterial biofilms: A common cause of persistent infections. Science 1999;284:1318-22.

25. Davies JC, Bilton D. Bugs, biofilms, and resistance in cystic fibrosis. Respir Care 2009;54:628-40.

26. Stoodley P, Sauer K, Davies DG, Costerton JW. Biofilms as complex differentiated communities. Annu Rev Microbiol 2002;56:187-209.

27. Mah T-F, Pitts B, Pellock B, Walker GC, Stewart PS, O’Toole GA. A genetic basis for Pseudomonas aeruginosa biofilm antibiotic resistance. Nature 2003;426:306-10.

28. Lewis K. Persister cells, dormancy and infectious disease. Nat Rev Micro 2007;5:48-56.

29. Hausner M, Wuertz S. High rates of conjugation in bacterial biofilms as determined by quantitative in situ analysis. Appl Environ Microbiol 1999;65:3710-3.

30. Ghigo JM. Natural conjugative plasmids induce bacterial biofilm development. Nature 2001;412:442-5.

31. Donlan RM, Costerton JW. Biofilms: Survival mechanisms of clinically relevant microorganisms. Clin Microbiol Rev 2002;15:167-93.

32. Chowdhury P, Sacks SH, Sheerin NS. Minireview: Functions of the renal tract epithelium in coordinating the innate immune response to infection. Kidney Int 2004;66:1334-44. 
33. Abbas AK, Lichtman AH, Pober JS. Cellular and Molecular Immunology, 3rd edn. Saunders: Philadelphia, 1997:250-76.

34. Curfs J, Meis M, Hoogkamp-Korstanje A. A primer on cytokines: Sources, receptors, effects, and inducers. J Clin Microbiol 1997;10:742-80.

35. Gürgöze MK, Akarsu S, Yilmaz E, et al. Proinflammatory cytokines and procalcitonin in children with acute pyelonephritis. Pediatr Nephrol 2005;20:1445-8.

36. Sheu JN, Chen MC, Cheng SL, Lee IC, Chen SM, Tsay GJ. Urine interleukin-1beta in children with acute pyelonephritis and renal scarring. Nephrology 2007;12:487-93.

37. Kassir K, Vargas-Shiraishi O, Zaldivar F, Berman M, Singh J, Arrieta A. Cytokine profiles of pediatric patients treated with antibiotics for pyelonephritis: Potential therapeutic impact. Clin Diagn Lab Immunol 2001;8:1060-3.

38. Dinarello CA. Interleukin-1 $\beta$. Crit Care Med 2005;33:S460-2.

39. Bonfield TL, Panuska JR, Konstan MW, et al. Inflammatory cytokines in cystic fibrosis lungs. Am J Respir Crit Care Med 1995; 152:2111-8.

40. Schuster A, Haarmann A, Wahn V. Cytokines in neutrophildominated airway inflammation in patients with cystic fibrosis. Eur Arch Otorhinolaryngol 1995;252:S59-60.

41. Jarvis WR, Martone WJ. Predominant pathogens in hospital infections. J Antimicrob Chemother 1992;29:19-24.

42. Pinna A, Usai D, Sechi LA, Molicotti P, Zanetti S, Carta A. Detection of virulence factors in Pseudomonas aeruginosa strains isolated from contact lens-associated corneal ulcers. Cornea 2008;27:320-6.

43. Le Berre R, Nguyen S, Nowak E, et al. Quorum-sensing activity and related virulence factor expression in clinically pathogenic isolates of Pseudomonas aeruginosa. Clin Microbiol Infect 2008;14:337-43.

44. Mittal R, Chhibber S, Sharma S, Harjai K. Macrophage inflammatory protein-2, neutrophil recruitment and bacterial persistence in an experimental mouse model of urinary tract infection. Microbes Infect 2004;6:1326-32.

45. Harjai K, Mittal R, Chhibber S, Sharma S. Contribution of TammHorsfall protein to virulence of Pseudomonas aeruginosa in urinary tract infection. Microbes Infect 2005; 7:132-7.

46. Mittal R, Sharma S, Chhibber S, Harjai K. Effect of macrophage secretory products on elaboration of virulence factors by planktonic and biofilm cells of Pseudomonas aeruginosa. Comp Immunol Microbiol Infect Dis 2006;29:12-26.

47. Ladd TI, Schmiel D, Nickel JC. The use of a radiorespirometric assay for testing the antibiotic sensitivity of catheter associated bacteria. J Urol 1987;138:1451-6.
48. Mittal R, Sharma S, Chhibber S, Harjai K. Iron dictates the virulence of Pseudomonas aeruginosa in urinary tract infections. J Biomed Sci 2008;15:731-41.

49. Mittal R, Sharma S, Chhibber S, Harjai K. Contribution of free radicals to Pseudomonas aeruginosa induced acute pyelonephritis. Microb Pathog 2008;45:323-30.

50. Garg UC, Ganguly NK, Sharma S, Chakravati RN, Bhatnagar RK. Quantitative histopathological method for evaluation of experimental ascending pyelonephritis. Med Sci Res 1987;15:367-8.

51. Wills ED. Mechanism of lipid peroxide formation in animal tissues. Biochem J 1965; 99:667-76.

52. Tugtepe H, Sener G, Cetinel S, Velioglu-Ogunç A, Yegen BC. Oxidative renal damage in pyelonephritic rats is ameliorated by montelukast, a selective leukotriene CysLT1 receptor antagonist. Eur J Pharmacol 2007;557:69-75.

53. Svanborg C, Bergsten G, Fischer H, et al. Uropathogenic Escherichia coli as a model of host-parasite interaction. Curr Opin Microbiol 2006;9:33-9.

54. Mak RH, Kuo HJ. Pathogenesis of urinary tract infection: An update. Curr Opin Pediatr 2006;18:148-52.

55. Rudner XL, Kernacki KA, Barrett RP, Hazlett LD. Prolonged elevation of IL-1 in Pseudomonas aeruginosa ocular infection regulates macrophage-inflammatory protein- 2 production, polymorphonuclear neutrophil persistence, and corneal perforation. J Immunol 2000;164:6576-82.

56. Jensen ET, Kharazami A, Lam K, Costerton JW, Hoiby N. Human polymorphonuclear leukocyte response to Pseudomonas aeruginosa grown in biofilms. Infect Immun 1990;58:2383-5.

57. Takeoka K, Ichimiya T, Yamasaki T, Nasu M. The in vitro effect of macrolides on the interaction of human polymorphonuclear leukocytes with Pseudomonas aeruginosa in biofilms. Chemotherapy 1998:44:190-7.

58. Walker TS, Tomlin KL, Worthen GS, et al. Enhanced Pseudomonas aeruginosa biofilm development mediated by human neutrophils. Infect Immun 2005;73:3693-701.

59. Pavlova EL, Lilova MI, Savov VM. Oxidative stress in children with kidney disease. Pediatr Nephrol 2005;20:1599-604.

60. Bille J, Glauser MP. Protection against chronic pyelonephritis in rats by suppression of acute suppuration: Effects of colchicine and neutropenia. J Infect Dis 1982;146:220-26.

61. Meylan PR, Markert M, Bille J, Glauser MP. Relationship between neutrophil-mediated oxidative injury during acute experimental pyelonephritis and chronic renal scarring. Infect Immun 1989;57:2196-202. 


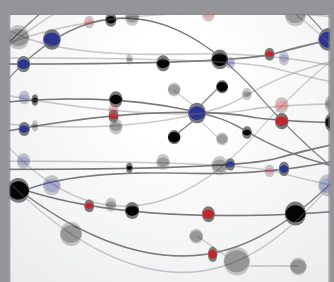

The Scientific World Journal
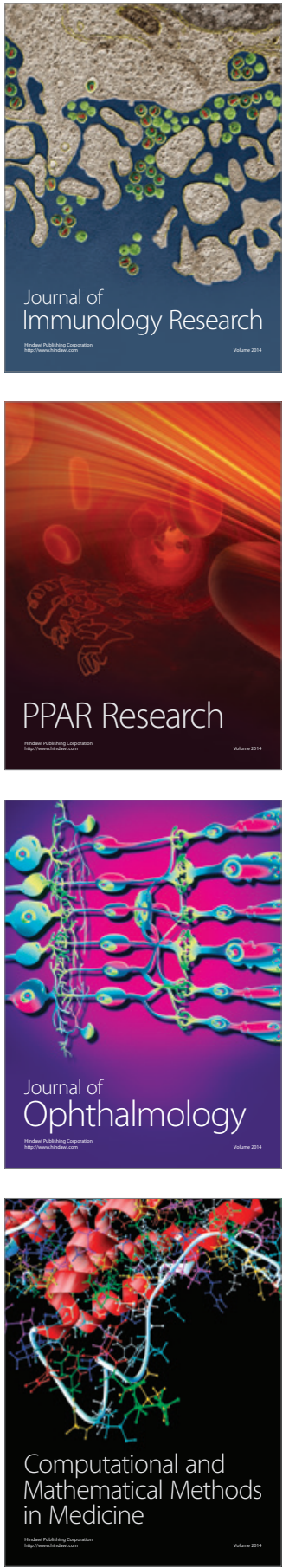

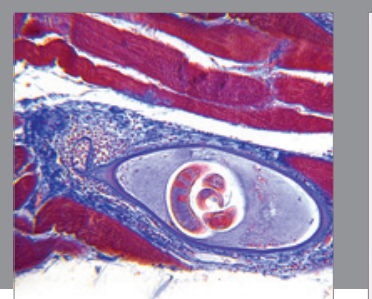

Gastroenterology Research and Practice

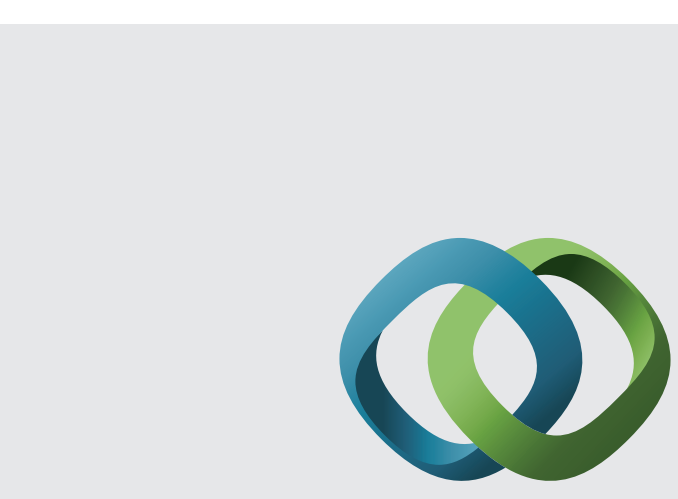

\section{Hindawi}

Submit your manuscripts at

http://www.hindawi.com
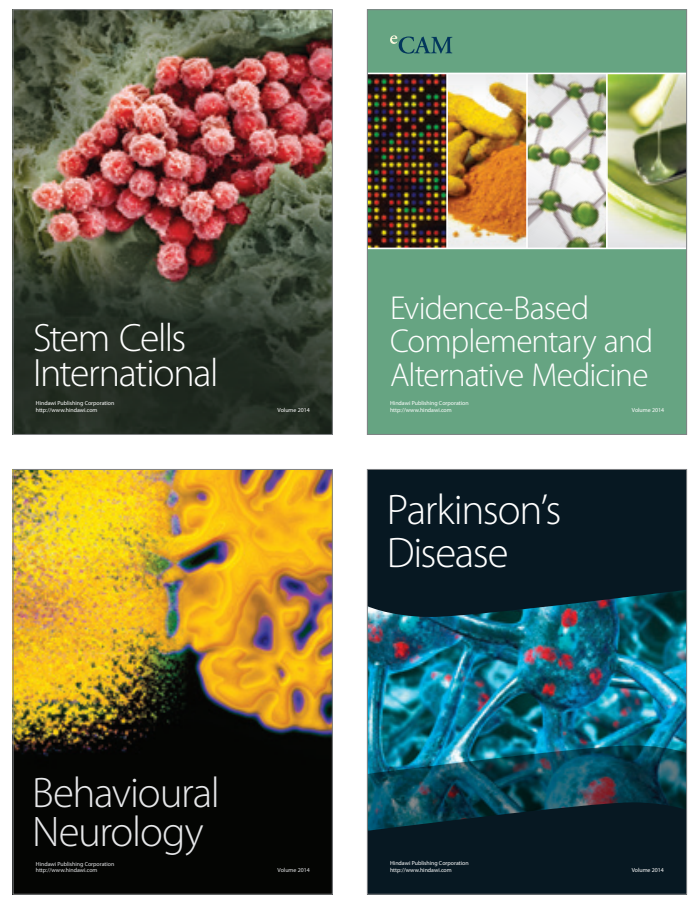
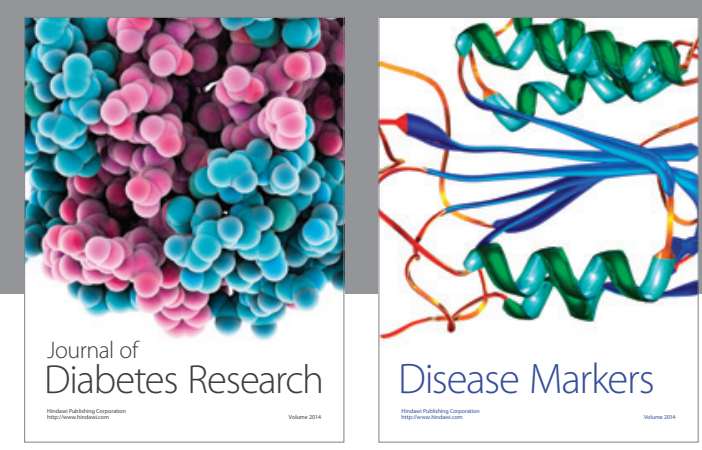

Disease Markers
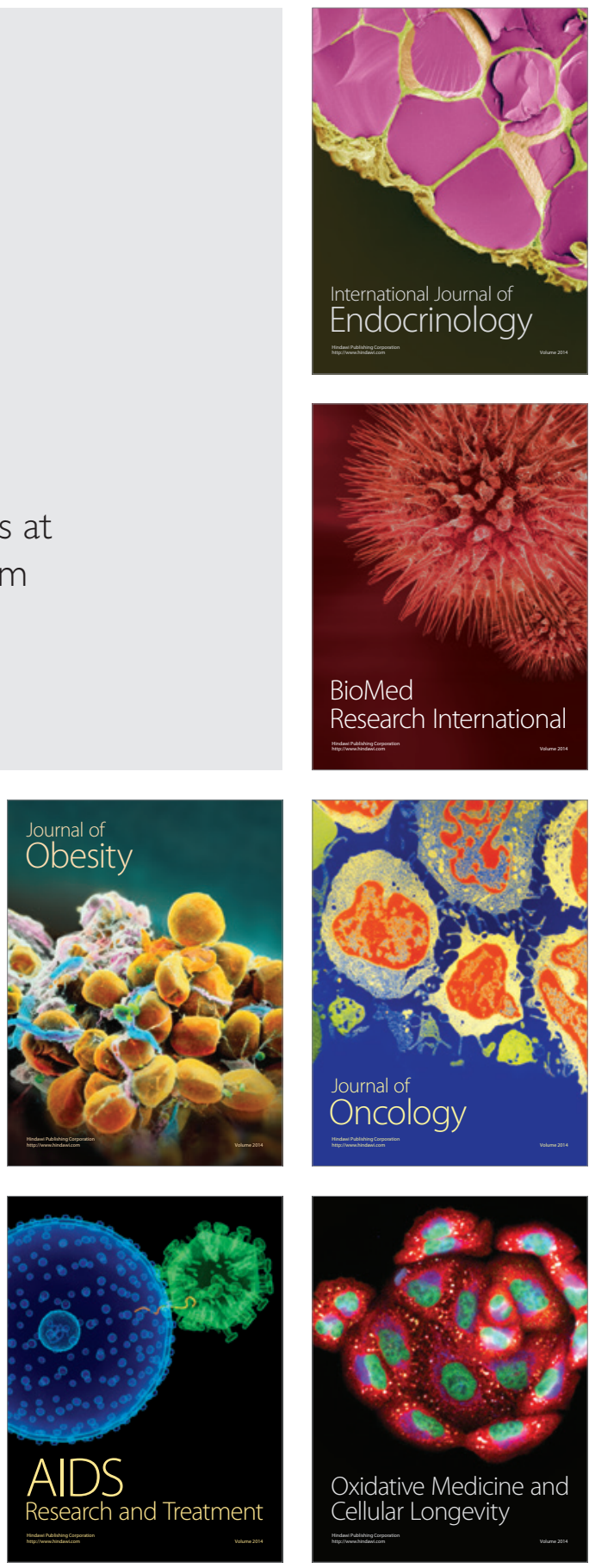